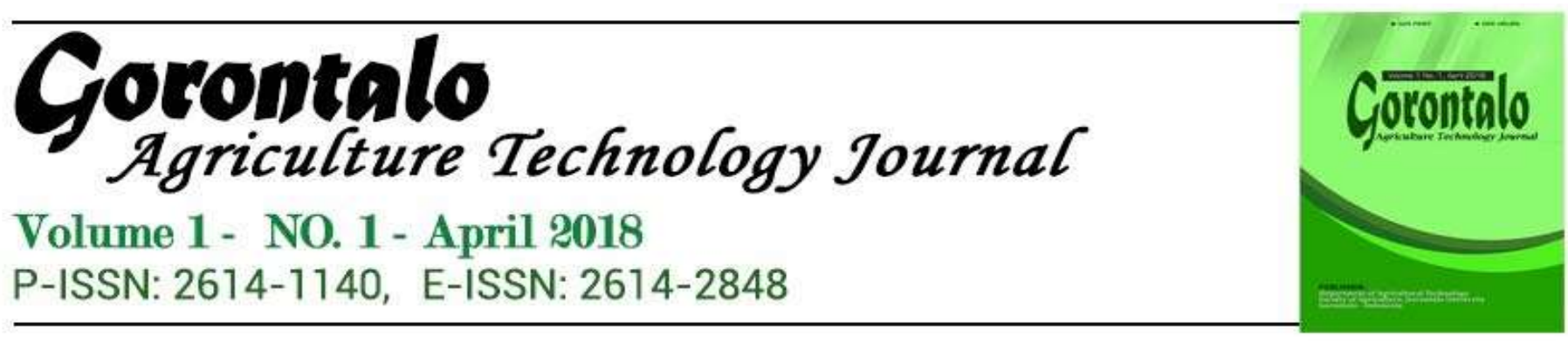

\title{
Pengaruh Perbandingan Tepung Ampas Kelapa dengan Tepung Terigu Terhadap Mutu Brownies
}

Irma Hasan 1)

\author{
1 Teknologi Hasil Pertanian Fakultas Pertanian Universitas Gorontalo
} email: irmahasan@gmail.com

\begin{abstract}
Abstrak
waste oil is the result addition to the manufacture of coconut milk, coconut meat processed into coconut oil of processing way wet be procured byproduct waste oil. until now utilization is limited to feed and partly be Tempe bongkrek for food. based on the analysis of waste oil still high-value when used as the flour for food ingredients high protein. this study aims untukmengetahui the influence of waste oil terhada water content, karbohidat and organoleptic (color, taste, aroma and texture) brownies.manfaat this study is to provide information on the broad about making brownies with the addition of flour waste oil and can be applied to the product food economic value because flour waste oil has a high content protein, low fat, and glutenfree. this study using the method is composed of creation phase flour waste oil and making process brownies. engineering data processing using the design of randomized complete (RAL), which consists of three treatment and three replicates. brownies the generated then in the test of the content of water content, level of carbohydrate and test organoleptic (color, taste, aroma and texture). of research results brownies of wheat flour and flour dregs coconut obtained highest average that is in the treatment with a comparison of wheat flour 55 grams and flour dregs coconut 45 grams with water content 39,0\%, comparison of wheat flour 75 grams and flour dregs coconut 25 grams grading carbohydrates $45,8 \%$ and test organoleptic each preferred by panelists terms of aroma, color, taste.
\end{abstract}

Keywords : Sago Flour, All Purpose Flour, Bread Flour, The Addition Of Sago

\section{PENDAHULUAN}

Ampas kelapa merupakan hasil samping pembuatan santan, daging buah kelapa yang diolah menjadi minyak kelapa dari pengolahan cara basah akan diperoleh hasil samping ampas kelapa. Sampai saat ini pemanfaatannya masih terbatas untuk pakan ternak dan sebagian dijadikan tempe bongkrek untuk makanan. Berdasarkan hasil analisis ampas kelapa masih bernilai tinggi bila dimanfaatkan sebagai tepung untuk bahan makanan yang berprotein tinggi. Menurut Derrik (2005), protein kasar yang terkandung pada ampas kelapa mencapai $23 \%$, dan kandungan seratnya yang mudah dicerna 
merupakan suatu keuntungan tersendiri untuk menjadikan ampas kelapa sebagai bahan pakan. Salah satu cara untuk meningkatkan daya guna protein dan nilai manfaat ampas kelapa yaitu dengan pendekatan bioteknologi melalui fermentasi yang memanfaatkan bakteri kapang Aspergillus oryzae, bakteri dimanfaatkan untuk meningkatkan nilai gizi bahan pakan terutama kandungan protein. Selain tidak bersifat patogen, A. oryzae juga dikenal sebagai kapang yang paling banyak menghasilkan enzim yaitu $\alpha$-amilase, $\alpha-$ galaktosidase, glutaminase, protease, dan $\beta$-glukosidase. Dari beberapa enzim ini yang paling penting adalah enzim protease dan amilase yang bekerja dalam pemecahan protein dan amilum dari substrat. Enzim $\alpha$-amilase memecah ikatan $\alpha-1,4$ menghasilkan glukosa, sedangkan $\beta$-glukosidase memecah ikatan $\beta-1,6$ pada rantai cabang dan dekstrin menjadi glukosa (Purwoko, 2007). Enzim protease yang dihasilkan kapang A. oryzae akan merombak rantai polimer yang panjang dari protein menjadi asam-asam amino sehingga akan menyebabkan terjadinya peningkatan kadar nitrogen asam amino dan asam total (Gandjar, 1977).

Menurut Derrik (2005), protein kasar yang terkandung pada ampas kelapa mencapai 23\%, dan kandungan seratnya yang mudah dicerna merupakan suatu keuntungan tersendiri untuk menjadikan ampas kelapa sebagai bahan pakan. Salah satu cara untuk meningkatkan daya guna protein dan nilai manfaat ampas kelapa yaitu dengan pendekatan bioteknologi melalui fermentasi yang memanfaatkan bakteri kapang Aspergillus oryzae, bakteri dimanfaatkan untuk meningkatkan nilai gizi bahan pakan terutama kandungan protein.

Tepung ampas kelapa digunakan sebagai bahan tambahan pembuatan brownies karena ampas kelapa dianggap sebagai limbah dan masih jarang sekali masyarakat memanfaatkan ampas kelapa serta mengurangi penggunaan tepung terigu. Ampas kelapa memiliki kandungan tinggi protein,rendah lemak,karbohidrat serta bebas gluten. Berdasarkan uraian tersebut penambahan ampas kelapa diharapkan dapat menghasilkan brownies yang mempunyai nilai gizi, tekstur dan citarasa yang disukai konsumen. Sehingga perlu dilakukan penelitian pemanfaatan limbah ampas kelapa dalam pembuatan brownies.

\section{METODE PENELITIAN}

\subsection{Alat dan Bahan}

Alat yang digunakan dalam pembuatan brownies antara lain yaiitu: timbangan, kom, mixer, talenan, pisau, panci kecil, pengaduk kayu, kompor, Loyang, oven. Peralatan kimia yang digunakan untuk analisis adalah timbangan analitik, cawan alimunium, cawan porselen, desikator, alumunium foil, waterbath, vakum, oven tanur.

Bahan yang di gunakan dalam pembuatan tepung ampas kelapa dan brownies antara lain: tepung ampas kelapa,tepung terigu, gula, telur, margarin, coklat batang, coklat bubuk. 


\subsection{Metode Penelitian}

Metode ini menggunakan metode rancangan acak lengkap ( RAL ) dengan subtitusi tepung ampas kelapa dengan tepung terigu dan tiap perlakuan di lakukan tiga kali ulangan, di mana :

A1 $=$ Tepung terigu 75 gram : Tepung ampas kelapa 25 gram

A2 = Tepung terigu 65 gram : Tepung ampas kelapa 35 gram

A3 = Tepung terigu 55 gram : Tepung ampas kelapa 45 gram

\subsection{Prosedur Penelitian}

\section{Pembuatan Tepung Ampas Kelapa} kelapa:

Berikut ini adalah tahap-tahap proses pengolahan tepung ampas

1. Pengeringan ampas kelapa

Pengeringan dilakukan untuk mengurangi kadar air. Proses pengeringan dilakukan dengan menggunakan oven pada temperatur $60-70^{\circ} \mathrm{C}$.

2. Penumbukan dan pengayakan

Penumbukan ampas kelapa kering ditumbuk hingga halus dengan menggunakan blender. Untuk menghasilkan tepung yang halus dan bersih, hasil ampas kelapa yang diblender disaring dengan menggunakan tapisan tepung.

3. Pengeringan akhir

Pengeringan akhir dilakukan agar tepung benar-benar kering dan mempunyai daya simpan yang relatif tinggi. Tepung ampas kelapa dikemas dan disimpan dalam ruangan kering, bersih, berventilasi udara baik, dan tidak terkena sinar matahari secara langsung.

\section{Pembuatan Brownies}

1. Bahan disiapkan terdiri dari tepung terigu dan tepung ampas kelapa sesuai perlakuan, telur ayam 3 butir,coklat bubuk 30 g,gula pasir 100 g,margarine $100 \mathrm{~g}$, coklat batang $150 \mathrm{~g}$

2. Alat - alat yang digunakan yaitu: Timbangan, baskom, mixer, talenan, pisau, panci kecil, pengaduk kayu, kompor, Loyang, oven.

3. Gula pasir dan telur di mixer selama 5 menit,di tambahkan coklat bubuk dan aduk rata.

4. Margarin dipanaskan, kemudian potongan coklat batang dimasukan dan diaduk - aduk hingga coklat meleleh.

5. Tepung terigu dan tepung ampas kelapa dimasukan kedalam coklat,yang telah dipindahkan kedalam Loyang,aduk dengan mixer. Kocokan telur ditambahkan dan diaduk hingga tercampur rata

6. Adonan brownies dituang kedalam Loyang cetakan yang telah dioles margarin dan diberi alas kertas roti.

7. Adonan brownies dipanggang didalam oven dengan temperatur $150^{\circ} \mathrm{C}$ selama 60 menit atau hingga brownies matang. 


\subsection{Parameter Pengamatan}

\section{Kadar Air (Sudarmadji et al., 1984)}

Bahan yang telah dihaluskan ditimbang sebanyak 2 gram kemudian dimasukan kedalam cawan (porselen) yang telah diketahui beratnya. Setelah itu bahan dikeringkan dalam desikator dan ditimbang. Bahan kemudian dikeringkan lagi dalam oven selama 30 menit, didinginkan dalam desikator dan kemudian ditimbang. Perlakuan ini diulangi sampai tercapai berat konstan. Perhitungan kadar air bahan dilakukan sebagai berikut :

$$
\% \text { Kadar Air }=\frac{\text { Bawat }=\text { Bakhir }}{\text { Bakhir }} X 100 \%
$$

\section{Analisis Karbohidarat (Sudarmadji et al, 1984)}

1. Timbangan 2-5 gram contoh berupa bahan padat yang telah da haluskan atau bahan cair dalam gelas piala $250 \mathrm{ml}$, tambahkan $50 \mathrm{ml}$ aqudest dan aduk selama 1 jam. Suspense disaring dengan kertas saring dan di cuci dengan aquadest sampai volume filtrate ini mengandung karbohidrat yang larut dan di buang.

2. Untuk bahan yang mengandung lemak maka pati yang terdapat sebagai menguap dan residu, kemudian cuci lagi dengan $150 \mathrm{ml}$ alcohol 10\% untuk membebaskan lebih lanjut karbohidrat yang larut.

3. Residu yang dipindahkan secara kuantitatif dari kertas saring kedalam Erlenmeyer dengan pencucian $200 \mathrm{ml}$ aquadestdan tambahkan $20 \mathrm{ml}$ HCL. Kurang lebih 25\% (berat jenis 1, 125) tutup dengan pendinginan balik dan panaskan diatas pemanas air mendidih selama 2,5 jam.

4. Setelah dingin netralkan dengan volume $500 \mathrm{ml}$ kemudian saring. Tentukan kadar gula yang dinyatakan sebagai glukosa dari fitrate yang diperoleh. Berat glukosa di kalikan 0,9 merupakan bara pati.

Rumus \% Karbohidrat (g/100g) $=-($ Protein + abu + air $)$

\section{Uji Organoleptik (Rahayu, 2001)}

Pengaturan terhadap cita rasa untuk menunjukkan penerimaan konsumen terhadap suatu bahan makanan umumnya di lakukan dengan alat indera atau di kenal dengan uji organoleptik. Uji ini menggunakan metode skala hedonik dan di lakukan pada 25 orang panelis.parameter yang di uji adalah aroma, rasa, warna, dan tekstur.

\section{HASIL DAN PEMBAHASAN}

\subsection{Kadar Air}

Keberadaan air dalam bahan pangan sering dihubungkan dengan mutu bahan pangan, sebagai pengukur bagian bahan kering atau padatan, penentu indeks kestabilan selama penyimpanan serta penentu mutu organoleptik terutama rasa dan keempukan ( Andarwulan dkk, 2011 ). 


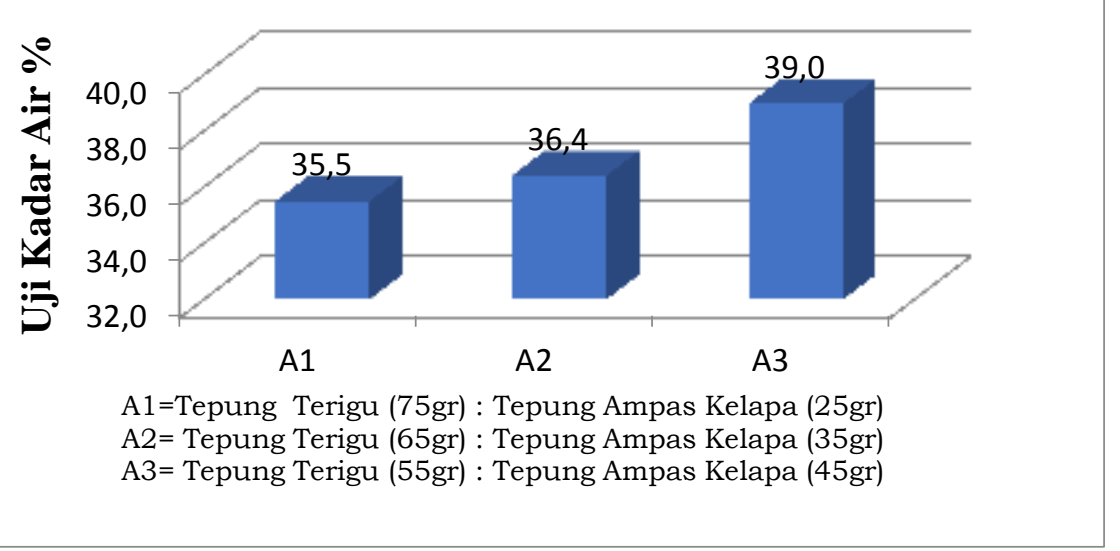

Gambar 1. Diagram Batang Kadar Air pada Brownies Ampas Kelapa

Dari hasil penelitian rata-rata kadar air brownies berkisar dari 35,5\% 39,0 \%. Pada perlakuan A3 ( tepung terigu 55 gram dan tepung ampas kelapa 45 gram ) lebih tinggi kadar airnya dibandingkan dengan perlakuan A1 ( tepung terigu 75 gram dan tepung ampas kelapa 25 gram ) dan A2 (tepung terigu 65 gram dan tepung ampas kelapa 35 gram ) dari gambar 3 dapat dilihat perbedaan nilai kadar air pada masing-masing perlakuan. Diduga adanya pengaruh penambahan tepung ampas kelapa dikarenakan tepung ampas kelapa memiliki kandungan serat yang tinggi sehingga semakin banyak tepung ampas kelapa yang digunakan maka semakin tinggi air yang dapat diikat. Sebab jika brownies kelebihan kadar air akan cepat rusak dan busuk,mempercepat masa simpan brownies.

Semakin banyak tepung ampas kelapa yang digunakan maka semakin tinggi kadar air brownies karena kelapa mempunyai kadar air yang lebih besar. Hal ini disebabkan karena kelapa mempunyai luas permukaan yang lebih kecil sehingga jumlah air yang bisa menguap tiap satuan waktu menjadi lebih kecil. Menurut Winarno (2004) faktor-faktor yang mempengaruhi pengeringan terutama adalah luas permukaan bahan, suhu pengeringan, aliran udara dan tekanan uap diudara.

\subsection{Kadar Karbohidrat}

Karbohidrat merupakan sumber kalori utama bagi hampir seluruh penduduk dunia, khususnya bagi penduduk negara yang sedang berkembang. Walaupun jumlah kolori yang dapat dihasilkan oleh 1 gram karbohidrat hanya $4 \mathrm{Kal}$ (kkal) bila disbanding protein dan lemak, karbohidrat merupakan sumber kalori yang murah. Selain itu beberapa golongan karbohidrat menghasilkan serat - serat ( dietary fiber ) yang berguna untuk pencernaan. ( Winar

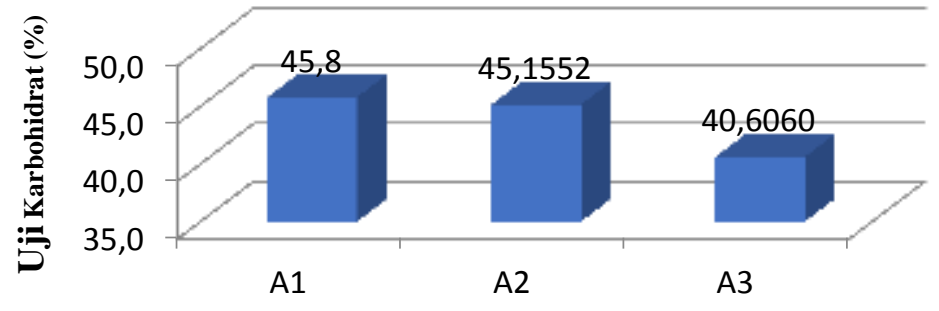

A1 $=$ Tepung Terigu (75gr) : Tepung Ampas Kelapa (25gr)

A2 $=$ Tepung Terigu (65gr) : Tepung Ampas Kelapa (35gr)

A3= Tepung Terigu (55gr) $:$ Tepung Ampas Kelapa (45gr) 
Gambar 2. Diagram Batang Kadar Karbohidrat pada Brownies Ampas Kelapa

Dari gambar 4 terlihat kadar karbohidrat pada setiap perlakuan berbeda. Kadar karbohidrat tertinggi terdapat pada perlakuan A1 (tepung terigu 75 gram dan tepung ampas kelapa 25 gram ) yaitu sebesar 45,8 ,sedangkan kadar karbohidrat terendah terdapat pada perlakuan A3 (tepung terigu 55 gram dan tepung ampas kelapa 45 gram) sebesar 40,6060.

Hal ini disebabkan semakin tinggi penambahan tepung ampas kelapa pada perlakuan,maka akan mengalami penurunan kadar karbohidrat. Karena Ampas kelapa karbohidratnya tidak terlalu tinggi sehingga nilai karbohidratnya rendah. Kadar karbohidrat mengalami penurunan seiring dengan banyaknya penambahan tepung ampas kelapa.

\subsection{Organoleptik Warna}

Warna merupakan komponen yang penting untuk menentukan kualitas atau derajat penerimaan suatu bahan pangan dan merupakan kriteria mutu dalam makanan terutama di tunjukan kepada konsumen (Winarno, 2004 ).

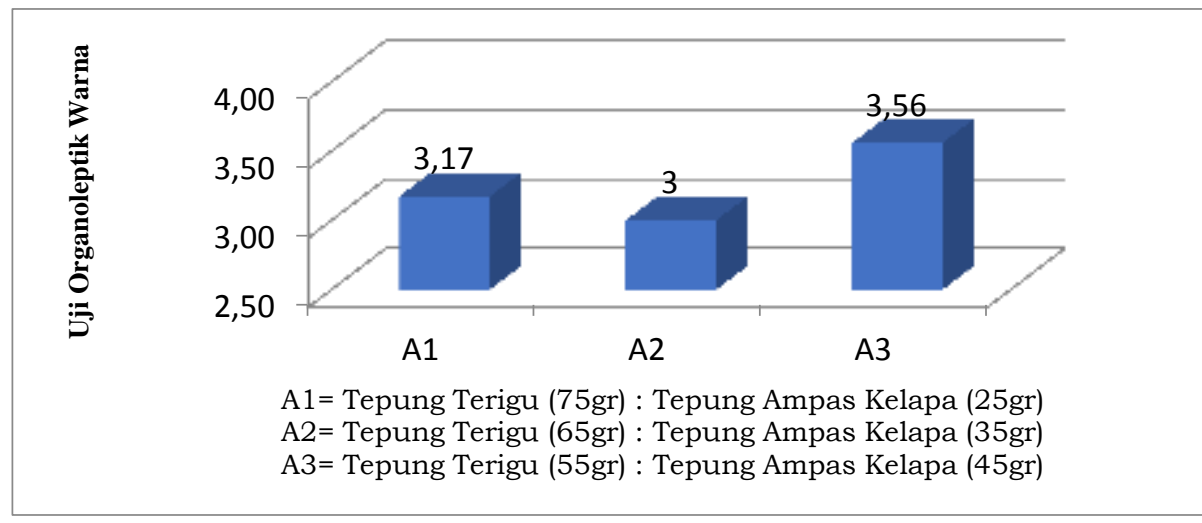

Gambar 3. Diagram Batang Uji Hedonik Warna pada Brownies Ampas Kelapa

Dari gambar 5 terlihat uji hedonic warna pada setiap perlakuan berbeda. Uji hedonic warna tertinggi terdapat pada perlakuan A3 (tepung terigu 55 gram dan tepung ampas kelapa 45 gram) yaitu sebesar 3,56, sedangkan uji hedonic warna terendah terdapat pada perlakuan A1 (tepung terigu 75 gram dan tepung ampas kelapa 25 gram ) sebesar 3.

Hal ini disebabkan karena warna dari perlakuan A3 (tepung terigu 55 gram dan tepumg ampas kelapa 45 gram) terlihat berbeda dari perlakuan A1 dan A2, karena A3 (tepung terigu 55 gram dan tepung ampas kelapa 45 gram) warnanya timbul karena adanya minyak yang ada dalam tepung ampas kelapa sehingga warnanya terlihat coklat kehitaman,disebabkan perpaduan antara minyak dan coklat sehingga terlihat jelas perbedaanya dari perlakuan lainnya.

\subsection{Organoleptik Rasa}


Rasa makanan merupakan parameter yang sangat penting. Rasa sangat menentukan makanan tersebut diterima atau tidak. Rasa dinilai dengan tanggapan rangsang kimiawi oleh lidah, dimana keseluruhan interaksi antara sifat-sifat aroma, rasa,dan warna merupakan keseluruhan rasa makanan yang dinilai. Setiap makanan memiliki rasa yang berbeda-beda.

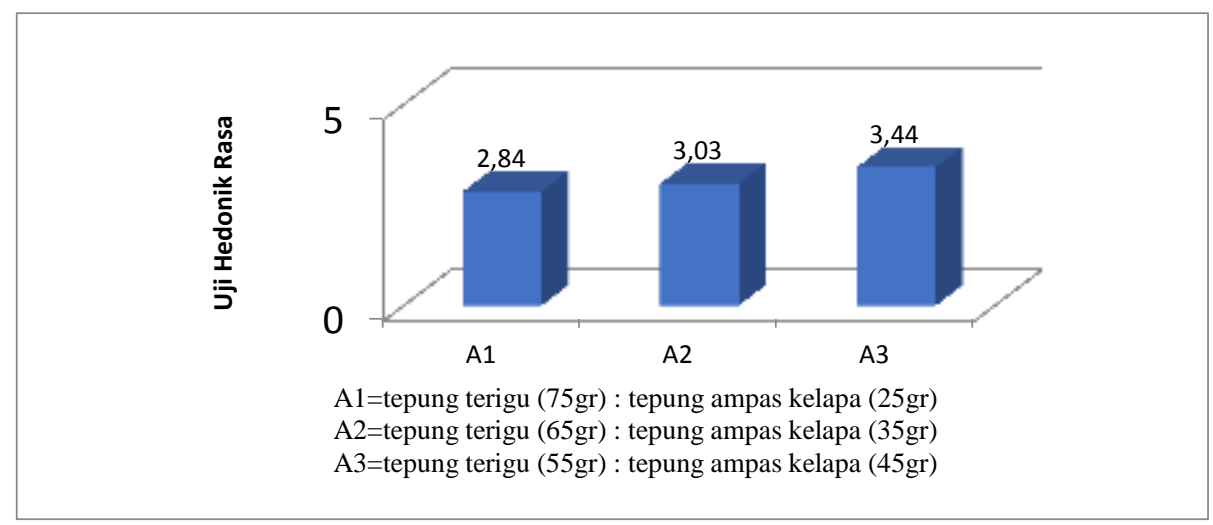

Gambar 4. Diagram Batang Uji Hedonik Rasa pada Brownies Ampas Kelapa

Dari gambar diatas terlihat uji hedonic rasa pada setiap perlakuan berbeda. Uji hedonic rasa tertinggi terdapat pada perlakuan A3 (tepung terigu 55 gram dan tepung ampas kelapa 45 gram ) yaitu sebesar 3,44, sedangkan uji hedonic rasa terendah terdapat pada perlakuan A1 (tepung terigu 75 gram dan tepung ampas kelapa 25 gram ) sebesar 2,84. Hal ini disebabkan karena semakin banyak penambahan tepung ampas kelapa pada brownies yang dihasilkan akan semakin berasa kelapa pada brownies, tepung ampas kelapa yang ditambahkan rasa kelapa akan semakin kuat. Karena tepung ampas kelapa memiliki rasa yang khas dibanding tepung terigu menimbulkan rasa yang lebih dominan dan rasa tidak terbiasa dengan lidah panelis, dikarenakan brownies yang sering dikonsumsi terbuat dari 100\% tepung terigu.

\subsection{Organoleptik Aroma}

Aroma makanan banyak menentukan kelezatan makanan tersebut, oleh karena itu aroma merupakan salah satu faktor penentuan mutu (2004), pada umumnya baik yang diterima oleh hidung dan otak banyak merupakan sebagai ramuan atau campuran empat baik utama yaitu harum, asam, tengik, dan hangus.

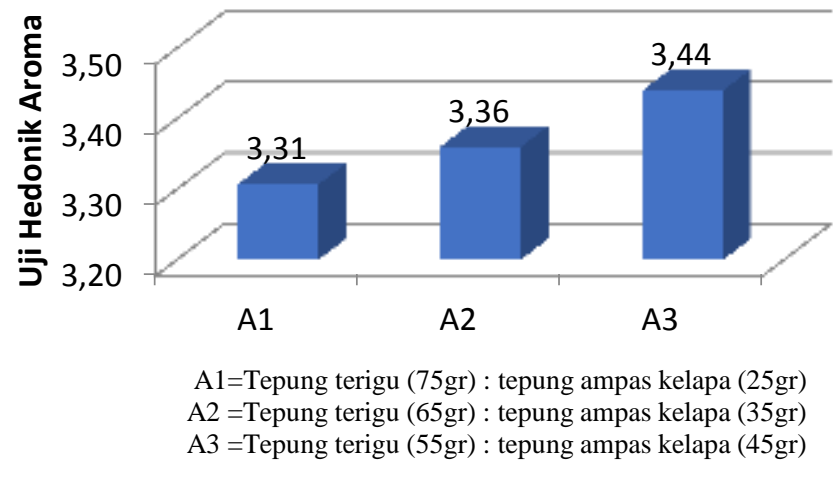


Gambar 5. Diagram Batang Uji Hedonik Aroma pada Brownies Ampas Kelapa

Dari gambar diatas terlihat uji hedonic aroma pada setiap perlakuan berbeda. Uji hedonic aroma tertinggi terdapat pada perlakuan A3 (tepung terigu 55gram dan tepung ampas kelapa 45 gram ) yaitu sebesar 3,44, sedangkan uji hedonic aroma terendah terhadap pada perlakuan A1( tepung terigu 55 gram dan tepung ampas kelapa 45 gram ) sebesar 3,31. Namun secera keseluruhan panelis menilai agak suka terhadap oroma dari brownies. Aroma brownies dapat dilihat dari bahan-bahan yang digunakan terutama tepung ampas kelapa yang dapat memberikan aroma khas kelapa yang berasal dari kelapa yang mampu memberikan aroma pada brownies. Aroma kelapa terjadi pada saat pngeringan ampas kelapa yang menyebabkan terbentuknya senyawa volatil.

\subsection{Organoleptik Tekstur}

Tekstur merupakan salah satu masalah yang sangat penting dalam industry dalam mempertahankan mutu dan keseragaman mutu. Dari gambar 8 terlihat uji hedonick tekstur pada setiap perlakuan berbeda. Uji hedonik tekstur tertinggi terdapat pada perlakuan A1 (tepung terigu 75 gram dan tepung ampas kelapa 25 gram) yaitu sebesar 33,33, sedangkan uji hedonik tekstur terendah terdapat pada perlakuan A3 (tepung terigu 55 gram dan tepung ampas kelapa 45 gram) sebesar 0,35. Hal ini dikarenakan hasil perlakuan dari pada A1 (tepung terigu 75 gram dan tepung ampas kelapa 25 gram) memiliki lebih banyak tepung terigu dibandingkan dengan perlakuan A3 (tepung terigu 55 gram dantepung ampas kelapa 45 gram) yang lebih banyak tepung ampas kelapa. Karena tepung terigu memiliki ciri yang khas yaitu mengandung gluten yang tidak dimiliki oleh jenis tepung lainnya. Gluten adalah suatu senyawa pada tepung terigu yang bersifat kenyal dan elastis.

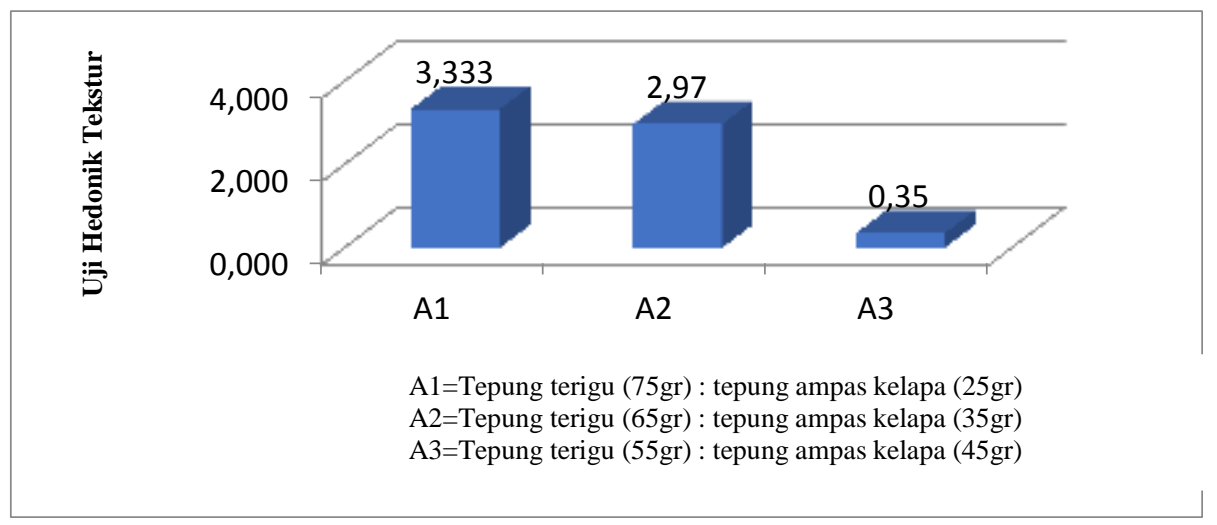

Gambar 6. Diagram Batang Uji Hedonik Tekstur pada Brownies Ampas Kelapa

\section{KESIMPULAN DAN SARAN}

\subsection{Kesimpulan}

Berdasarkan hasil pengamatan,analisa serta daya yang diperoleh dari hasil penelitian pembuatan brownies dari uji pengaruh penambahan tepung ampas kelapa terhadap mutu brownies, maka dapat disimpulkan sebagai berikut : 
1. Kadar air adalah : A3 dengan rata-rata 39,0\% dengan perbandingan tepung ampas kelapa 45 gram dan tepung terigu 55 gram

2. Kadar karbohidrat tertinggi pada A1 dengan rata-rata $45,8 \%$ dengan perbandingan tepung ampas kelapa 25 gram dan tepung terigu 75 gram.

3. Uji organoleptik Warna A3 3,56\%, aroma A3 3,44\% rasa A3 3,44 dan tekstur A1 3,33.

\subsection{Saran}

Sebaiknya dalam penelitian berikutnya dilanjutkan dengan masa simpan dari brownies yang dihasilkan.

\section{REFERENSI}

Miskiyah .,Mulyawati Ira., dan Haliza Winda. 2006. Pemanfaatan Ampas Kelapa Limabah Pengolahan Minyak Kelapa Murni Menjadi Pakan. Diakses Tahun 2016.

Mulyati Anis. 2015. Pembuatan Brownies Panggang dari Bahan Tepung Talas (Colocasia gigantean Hook F.) Komposit Tepung Ubi Jalar

Ungu dengan Penambahan Lemak yang Berbeda. Diakses Tahun 2017.

Sanusi. 2010. Ragam Kreasi Brownies Manis Nan Cantik. Yogyakarta: Flashbooks.

Ridhoresmi Diah. 2012. Pengaruh Substitusi Tepung Ampas Tahu Terhadap

Kadar Protein dan Daya Terima Brownies Kukus

Rahayu, 2001. Uji Organoleptik.

Sutomo, Budi. 2012. Rahasia Sukses Membuat Cake, Roti, Kue Kering \& Jajan Pasar. Nsbooks .

Setiawati, Rahimsyah A, Ulyarti. 2015. Kajian Pembuatan Brownies Kaya

Serat Dari Tepung Ampas Kelapa. Diakses Tahun 2017.

Yeni, Saniyani. 2007. Pembuatan Brownies yang Lezat dan Murah. Femina.

Hidayat, S. 2008. Kasiat Herbal Berdasarkan Warna, Bentuk, Rasa, Aroma, dan Sifat. Jakarta: PT. Media.

Wahyuningsih, Sri. 2014. Komposisi proksimat tingkat kekerasan dan daya terima brownies yang dibuat dengan menggunakan jenis telur yang berbeda. Universitas mohammadiyah Surakarta. 